\title{
Populations of two prey nematodes and their interaction are controlled by a predatory nematode
}

\author{
Giovanni A. P. dos Santos ${ }^{1,2, *}$, Tom Moens ${ }^{1}$ \\ ${ }^{1}$ Marine Biology Section, UGent, Krijgslaan 281 (S8), 9000 Ghent, Belgium \\ ${ }^{2}$ Universidade Federal de Pernambuco, Departamento de Zoologia, Av. Prof. Moraes Rego, s/n, Cidade universitária, Recife, \\ Pernambuco CEP: 50670-901, Brazil
}

\begin{abstract}
Many nematode species are candidate predators of other nematodes. However, the impact of predation on prey population dynamics and assemblage structure is unknown. We performed microcosm experiments in which the effect of the predacious nematode Enoploides longispiculosus on the population development of 2 prey nematode species, Diplolaimelloides meyli and D. oschei, was investigated at different predator abundances. One experiment used monospecifc prey populations, another used a mixed assemblage with both prey species. With monospecific prey populations, abundances of both prey species decreased with increasing predator abundances. Sizeselective predation released small juveniles (J1, J2) completely, and older juveniles (J3, J4) partly, from predation. Since previous studies had demonstrated that $D$. meyli partially inhibits population development of $D$. oschei in the absence of predators, and Enoploides prefer D. oschei over D. meyli, we expected predation to emphasize the dominance of $D$. meyli over $D$. oschei in mixed prey populations. However, our results showed the opposite, viz. strong inhibition of $D$. oschei by $D$. meyli in control microcosms without predators, and decreasing inhibitory effects at increasing predator abundance, resulting in more equitable abundances of both prey species. Predation thus alleviated the inhibitory effect of 1 prey species over the other. We conclude that predatory nematodes like Enoploides exert pronounced effects on their prey populations, but are unlikely to drive individual prey populations to extinction. Further, predator effects on prey assemblage structure depend as much on indirect effects as on direct predator-induced prey mortality. Experiments with more complex and natural species combinations are required to allow proper assessment of the importance of the present findings for natural assemblages.
\end{abstract}

KEY WORDS: Predatory control $\cdot$ Predator-prey interaction $\cdot$ Predatory nematodes $\cdot$ Bacterivorous nematodes $\cdot$ Population development $\cdot$ Assemblage structure $\cdot$ Horizontal interactions

\section{INTRODUCTION}

Top-down forces are a dominant ecological determinant of community biomass and structure (Hairston et al. 1960, Paine 1966, Hassell \& May 1986, Murdoch \& Briggs 1996, Vander Zanden et al. 2005, Gruner et al. 2008). Predators, and predator removals, can cause drastic shifts in densities and species composition (Frank et al. 2005). Direct predator-prey interactions are often important in determining the stability of bio- diversity and ecosystem functioning (Ives et al. 2005). Predator controls over prey populations are particularly important in many marine communities (e.g. Ambrose 1984b, 1991, Wilson 1990, Connolly \& Roughgarden 1999, Menge 2000), where they have been particularly well-documented in relation to fisheries impacts (Cury et al. 2003, Chassot et al. 2005, Gascuel 2005). In benthic communities, predation has been shown to affect larval recruitment (Olafsson et al. 1994, Desroy et al. 1998, Beukema \& Dekker 2005), 
and reduce macro-infaunal abundances both directly (Reise 1985, Strasser 2002) and indirectly (Ambrose 1984a,c, Commito \& Ambrose 1985, Posey et al. 1995, 2002, 2005, Menge 2000, Baden \& Boström 2001). Much less is known about predator controls on meiobenthic communities (Bell \& Coull 1978, Sutherland et al. 2000, Olafsson 2003).

Nematodes are the most abundant and among the most diverse metazoans in marine and terrestrial ecosystems (Heip et al. 1985, Wall \& Moore 1999, Yeates et al. 2009), feeding on a range of different sources (Moens \& Vincx 1997). While many nematodes are considered bacterial and microalgal feeders, there is a large variety of species which, judging from stoma morphology, are candidate predators of other meiobenthos, including nematodes, copepods, oligochaetes, and ciliates, as well as of settling larvae of macrofauna (Watzin 1983, 1985, Kennedy 1994, Moens \& Vincx 1997, Hamels et al. 2001). A limited number of observational (Moens \& Vincx 1997) and stable isotope studies (Moens et al. 2005, RzeznikOrignac et al. 2008) largely support the predatory ecology of various nematode genera abundant in intertidal and shallow subtidal sediments. Short-term (from minutes to $48 \mathrm{~h}$ ) experiments on the predation rates of 2 marine (Moens et al. 2000, Gallucci et al. 2005) and several terrestrial nematode species (Nelmes 1974, Bilgrami \& Jairajpuri 1989, Khan et al. 1991, Bilgrami \& Gaugler 2005, Bilgrami et al. 2005, Khan \& Kim 2007) have led to suggestions of potentially significant controls by predatory nematodes over their prey populations. Field data on horizontal (Gallucci et al. 2005) and vertical (Steyaert et al. 2001) distributions of abundant predacious marine nematodes in relation to the abundances of their prey assemblages further support this idea. However, only few studies have investigated effects of predatory nematodes on prey nematode population dynamics and/or biomass, and those which have been published all pertain to terrestrial assemblages (Mikola \& Setälä 1998, Mikola 1998, Bilgrami \& Gaugler 2005, Bilgrami et al. 2005, Khan \& Kim 2005, 2007).

Moreover, the local diversity of nematode assemblages tends to be (very) high (Heip et al. 1985, Wall \& Moore 1999, Yeates et al. 2009), and competitive, facilitative, and inhibitory interactions, even among closely related species, are important in shaping these assemblages (Mikola 1998, Ilieva-Makulec 2001, PostmaBlaauw et al. 2005, De Mesel et al. 2006, dos Santos et al. 2009). It is unclear whether, and to what extent, predatory forces interfere with these horizontal interactions and affect assemblage structure and diversity.

Here we focused on 2 different but closely related prey nematode species (Diplolaimelloides meyli and D. oschei), which occur sympatrically on decomposing
Spartina detritus in salt marshes. These 2 bacterivorous species negatively affect each other's population development in laboratory microcosm experiments in the absence of predators, with $D$. meyli having a stronger inhibitory effect on $D$. oschei than vice versa (De Mesel et al. 2006, dos Santos et al. 2009). They have been shown to be very suitable prey for Enoploides (Moens et al. 1999, 2000, Gallucci et al. 2005). Moreover, Enoploides exhibited a preference for $D$. oschei over $D$. meyli (Moens et al. 2000, where D. oschei was erroneously reported as Monhystera sp.).

We performed microcosm experiments in which Enoploides were introduced into populations of either prey species, or of both prey species together. We assessed predatory effects of Enoploides on (1) the population development and age/size distribution of both prey species, and on (2) their relative abundances when both prey species were simultaneously present. We also assessed (3) predator-abundance dependence and (4) prey-size dependence of such predatory effects. In view of the above-mentioned preferential predation of Enoploides on Diplolaimelloides oschei, we hypothesized that any predator control on $D$. oschei would be stronger than that on $D$. meyli. In combination with the inhibitory interactions among both prey species, we expected predation to further emphasize the dominance of $D$. meyli over $D$. oschei in the mixed culture experiment.

\section{MATERIALS AND METHODS}

Nematodes. The prey nematode species Diplolaimelloides meyli and D. oschei (Monhysteridae) were harvested from permanent monospecific, agnotobiotic cultures on agar, fed unidentified bacteria from their original habitat (i.e. decaying Spartina anglica leaves in the Paulina salt marsh, located in the polyhaline reach of the Westerschelde Estuary, SW Netherlands; Moens \& Vincx 1998). For our experiments, prey nematodes were handpicked on the tip of a fine tungsten wire, rinsed twice in artificial seawater (ASW; Dietrich \& Kalle 1957) to remove most attached bacteria, and stored in ASW for $24 \mathrm{~h}$ at $5^{\circ} \mathrm{C}$ to allow fairly simultaneous inoculation into all experimental units.

The predatory nematode Enoploides longispiculosus was harvested from the upper $2 \mathrm{~cm}$ of the sediment at an intertidal flat bordering the Paulina salt marsh. Nematodes were extracted alive from freshly collected sediment by repeated decantation with tap water over a $63 \mu \mathrm{m}$ mesh sieve. Nematodes retained on the sieve were collected with ASW, and Enoploides were sorted at the genus level under a compound microscope. They were stored overnight in ASW prior to their inoculation into the experimental microcosms. Only adult 
and fourth-stage juvenile (J4) Enoploides were used for this experiment. Microscopic identification of several tens of Enoploides specimens has shown that E. longispiculosus is by far the dominant, but not the only, Enoploides species at this location. Substantially $<10 \%$ of the Enoploides present are E. spiculohamatus, a species which differs from E. longispiculosus mainly by the presence of small perforations in its mandibles and by slight differences in spicule length and distance of precloacal supplements to the cloaca. These differences are not visible under a compound microscope, hence monospecificity of the predator in our experiments is not guaranteed. However, >90\% dominance of E. longispiculosus is guaranteed. For information on the geographical distribution of these predator and prey species, we refer to the online database NeMys (http://nemys.ugent.be).

The predator-prey combination used in our experiments is artificial, in that this particular predator species is not usually found in the same type of sediments as these prey species. The latter abound on macroalgal wrack and in salt-marsh sediments with relatively high silt content (dos Santos et al. 2009), whereas the former is typical of fine- to mediumgrained sandy sediments with very low silt percentages (Gallucci et al. 2005). At the Paulina site, they occur at very nearby stations (separated by only a few tens of meters). Our reasons for choosing this model 'assemblage' are the following: (1) Enoploides is a very common and often abundant marine predator genus. (2) It has been shown to remain active in laboratory incubations on different substrata, including agar, for periods up to several weeks. (3) Diplolaimelloides meyli and $D$. oschei occur sympatrically on salt marsh detritus and in sediments. (4) They are easy to culture in the lab, and their life history and mutual interactions have been well studied (Moens \& Vincx 2000a,b, dos Santos et al. 2008, 2009). They are in fact 2 of the only 3 marine nematode species for which interspecific inhibitory interactions have been well documented (De Mesel et al. 2006, dos Santos et al. 2009). (5) They are suitable prey to Enoploides (Moens et al. 1999, Gallucci et al. 2005). We believe that the relevance of this artificial assemblage is high because the sympatric occurrence of closely related, often congeneric, nematode species is prevalent in a majority of marine sediments (Heip et al. 1985, De Mesel et al. 2006), and because predators are prominently present in many marine nematode assemblages (Heip et al. 1985, Gallucci et al. 2005).

Experiments. Experimental microcosms consisted of Petri dishes (5 cm i.d.) bottom-covered with $4 \mathrm{ml}$ of $0.75 \%$ bacto-agar medium with a salinity of 25 and a $\mathrm{pH}$ of 7.5 to 8 . Aliquots $(50 \mu \mathrm{l})$ of frozen-and-thawed Escherichia coli (strain K12) at a density of $3 \times 10^{9}$ cells $\mathrm{ml}^{-1}$ were added as a food source for the prey nematodes, since this food source and density support optimal population growth of both Diplolaimelloides species (dos Santos et al. 2008). Since nematodes are not capable of synthesizing several essential lipids when on a purely bacterial diet, cholesterol was added to the agar medium at $100 \mu g \mathrm{l}^{-1}$ (Vanfleteren 1980). Twenty adult prey specimens (10 males +10 gravid females) of either species were transferred individually to a $50 \mu \mathrm{l}$ drop of sterile ASW on the agar surface of the experimental units. The microcosms were then incubated for $20 \mathrm{~d}$ at $17^{\circ} \mathrm{C}$ in the dark to allow prey population establishment. There were 2 main experiments: one in which only a single prey species was present per microcosm (SS, single-species experiment: $20 D$. meyli or 20 D. oschei), and one in which both prey species were inoculated together into the microcosms (MIX, mixed-species experiment: 20 D. meyli + $20 \mathrm{D}$. oschei). Possible implications of this difference in prey nematode abundance between SS and MIX treatments are addressed in the 'Discussion'.

After these $20 \mathrm{~d}$, predatory nematodes were added in much the same way as the prey nematodes, in 4 different predator abundance treatments in each main experiment: 5, 15, 25, and 40 predators microcosm ${ }^{-1}$. A fifth treatment without predators served as a control. Only occasional mortality of predators occurred during or after their inoculation into the microcosms, and all such dead predators encountered throughout the experiment were replaced by new individuals, freshly collected from the field.

There were 3 replicates per treatment. Counts of total prey nematode numbers, early-stage juveniles $(\mathrm{J} 1, \mathrm{~J} 2)$, late-stage juveniles (J3, J4), adult males, adult females, and dead prey were performed just prior to predator inoculation and 5, 10, 15, and $20 \mathrm{~d}$ after inoculation of the predators.

Data analysis. Prey variables were compared among experiments, treatments, and time using a Generalized Linear Mixed Models (GLIMMIX) procedure in SAS v.9.2 (SAS Institute). A completely randomized statistical design was used with prey species densities in the SS and MIX experiments as the response variable and predatory effects (predator abundance) as the categorical variable. Given the nature of our data, where observations at different moments in time are interdependent, repeated measures analysis provided the most suitable model. We used the random statement to correct for the random effect of replicates and the interdependence of the repeated observations (replicate versus time). In the event of a significant F-statistic, a posteriori pairwise comparisons within factors or interaction terms used the Tukey-Kramer mean comparisons procedure, which properly controls the Type I error. 


\section{RESULTS}

\section{Total prey population}

Diplolaimelloides oschei total abundances (including adults and all larval stages) in the SS experiment differed highly significantly between treatments $(F=$ 53.10; $\mathrm{p}<0.0001)$ and between treatments versus time $(F=8.32 ; \mathrm{p}<0.0001)$. The control (0 predators) treatment exhibited a monotonous increase with time until $15 \mathrm{~d}$ after predator inoculation in the other treatments, followed by a population decline at the last count. Treatments with low predator densities (5 and 15) followed a similar population development but with significantly ( $p \leq 0.01$ ) lower densities at all but the last count. The 40-predator treatment yielded significantly lower prey densities than all but the 25-predator treatments ( $\mathrm{p} \leq 0.01$; Fig. 1A,B).

Diplolaimelloides oschei abundances in the MIX experiment also differed significantly between treat-

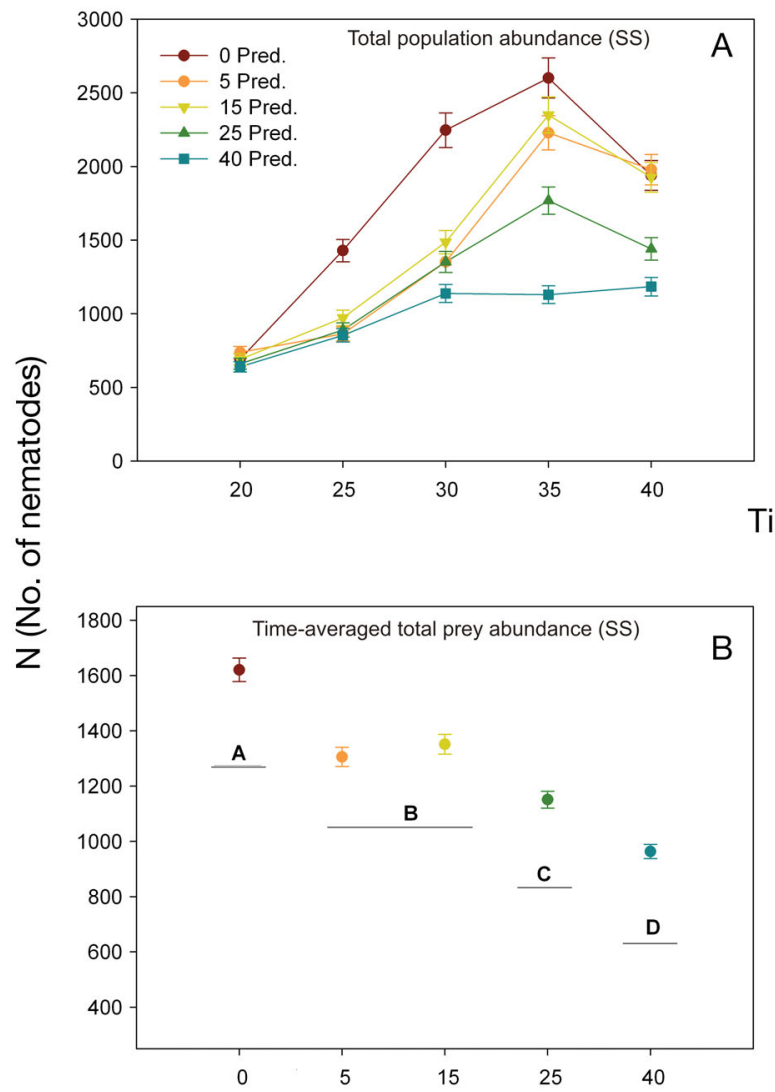

ments $(F=4.67 ; \mathrm{p}<0.05)$ and between treatments versus time $(F=3.25 ; \mathrm{p}<0.01)$. The control treatment exhibited a comparable increase over time as in the SS experiment, but the maximum abundance was only half that of the SS experiment. Similarly, abundances of $D$. oschei in the predator treatments of the MIX experiment were considerably lower than in the SS experiment $(\mathrm{p}<0.0001)$. Moreover, D. oschei abundances in the MIX experiment exhibited only minor differences between treatments (most $\mathrm{p} \geq 0.07$; Fig. 1C,D).

Diplolaimelloides meyli total abundances in the SS experiment differed significantly between treatments $(F=10.24 ; \mathrm{p}<0.01)$ and between treatments versus time $(F=4.82 ; \mathrm{p}<0.0001) . D$. meyli abundances in the controls significantly exceeded those in predator treatments (with the exception of the 15-predator treatment) throughout the experiment, with lowest prey abundance at the highest predator abundance (Fig. 2A,B). However, differences between treat-
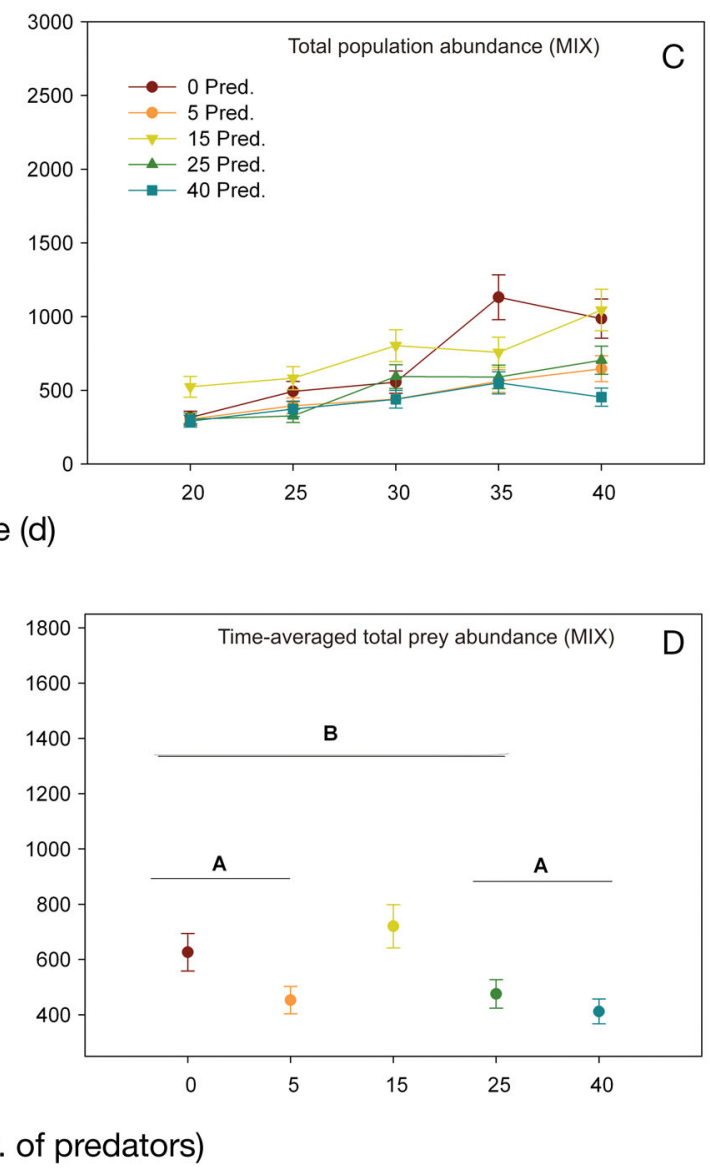

Fig. 1. Diplolaimelloides oschei. (A) D. oschei (single species, SS) (C) D. oschei (mixed species, MIX) total population abundance as a function of time in 4 different predator treatments and a control without predators. Predator abundance effects on total (B) D. oschei (SS) numbers and (D) D. oschei (MIX) abundances. (A,C): means \pm 1 SE of 3 replicates per treatment; (B,D): timeaveraged (from counts on Days 25, 30, 35, and 40) means \pm 1 SE of 3 replicates. Colour in circles of (B,D) corresponds to that in symbols in $(\mathrm{A}, \mathrm{C})$. Treatments indicated by the same letter did not differ significantly at $\mathrm{p}<0.05$ 


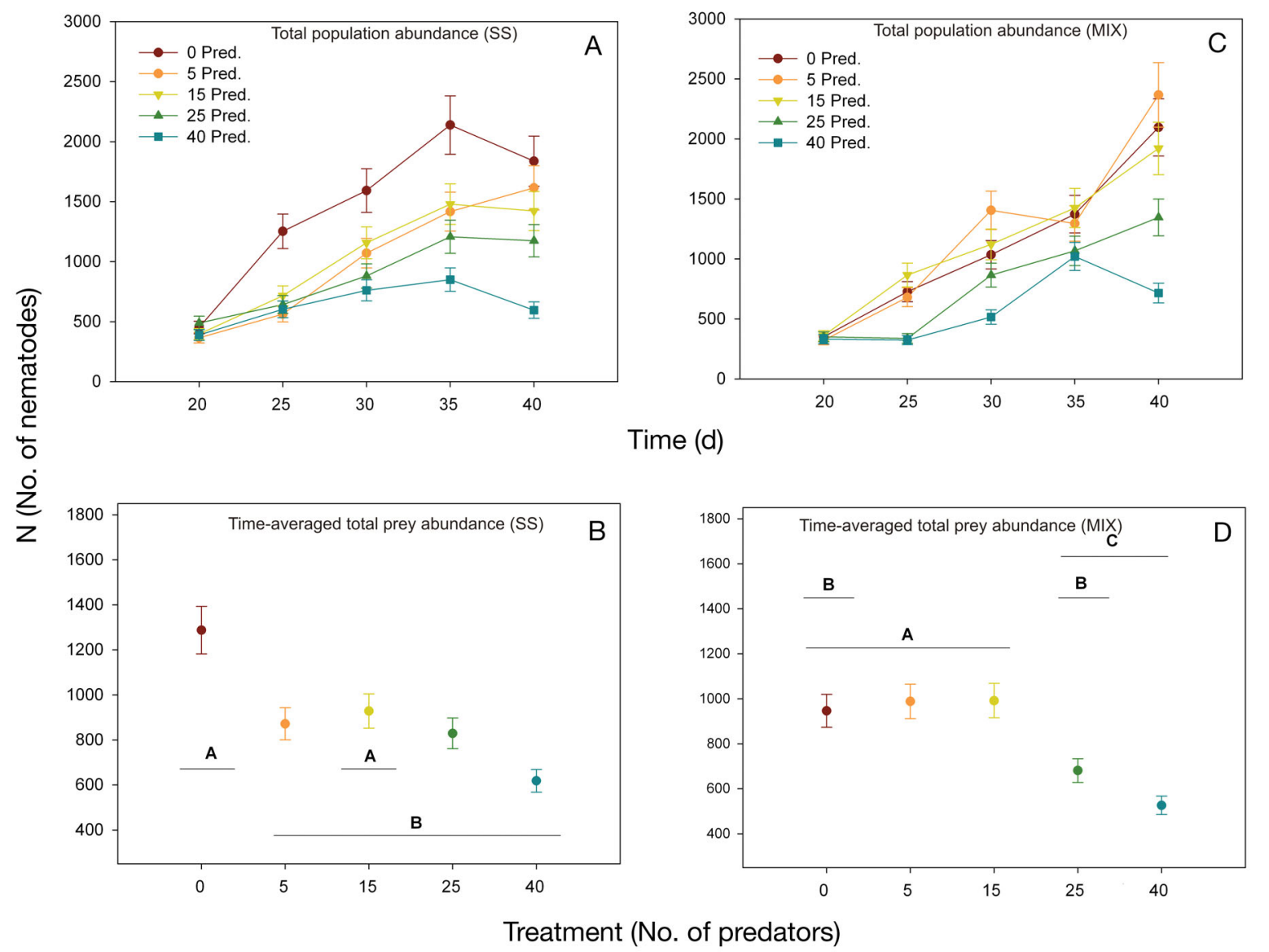

Fig. 2. Diplolaimelloides meyli. As in Fig. 1, but for D. meyli

ments with different predator abundances were not significant.

Diplolaimelloides meyli total abundances in the MIX experiment also differed highly significantly between treatments $(F=13.31 ; \mathrm{p}<0.001)$ and between treatments versus time $(F=5.73 ; \mathrm{p}<0.0001)$. However, there were no significant differences between the control, the 5-predator, and the 15-predator treatment $(\mathrm{p}>$ 0.05). At the highest predator abundance, D. meyli abundances were significantly lower $(p<0.05$; Fig. 2C,D). Overall, the abundances of $D$. meyli in the SS and MIX experiments did not differ $(p=0.25)$.

All main effects and interactions (experiment [SS versus MIX] versus treatment [predator abundance] versus prey [Diplolaimelloides oschei versus D. meyli] versus time), with the exception of experiment versus treatment and experiment versus prey versus treatment, on the total population abundances of both prey species were significant (Table S1 in the Supplement at www.int-res.com/articles/suppl/m427p117_ supp.pdf).

When we sum the abundances of Diplolaimelloides meyli and D. oschei in the SS experiment, we can com- pare the total prey abundances between SS and MIX. The MIX experiment yielded a significantly lower total prey abundance than the SS experiments over the complete incubation time $(\mathrm{p}<0.0001$; Fig. S1A-C in the Supplement at www.int-res.com/articles/suppl/ m427p117_supp.pdf).

\section{Early-stage juveniles (J1, J2)}

Abundances of Diplolaimelloides oschei first- and second-stage juveniles (J1 and J2) in the SS experiment differed highly significantly between treatments $(F=24.15 ; \mathrm{p}<0.0001)$ and treatments versus time $(F=$ $3.71 ; \mathrm{p}<0.001)$, mainly as a result of the highest 2 predator abundance treatments during the last $15 \mathrm{~d}$ of the experiment (Fig. 3A,B). In the MIX experiment, treatment no longer had a significant effect $(F=3.32$; $\mathrm{p}=0.06)$, but treatments versus time had $(F=2.19 ; \mathrm{p}<$ $0.02)$, indicating different temporal dynamics of prey abundances in different treatments (Fig. 3C,D).

Abundances of Diplolaimelloides meyli first- and second-stage juveniles in the SS experiment differed 


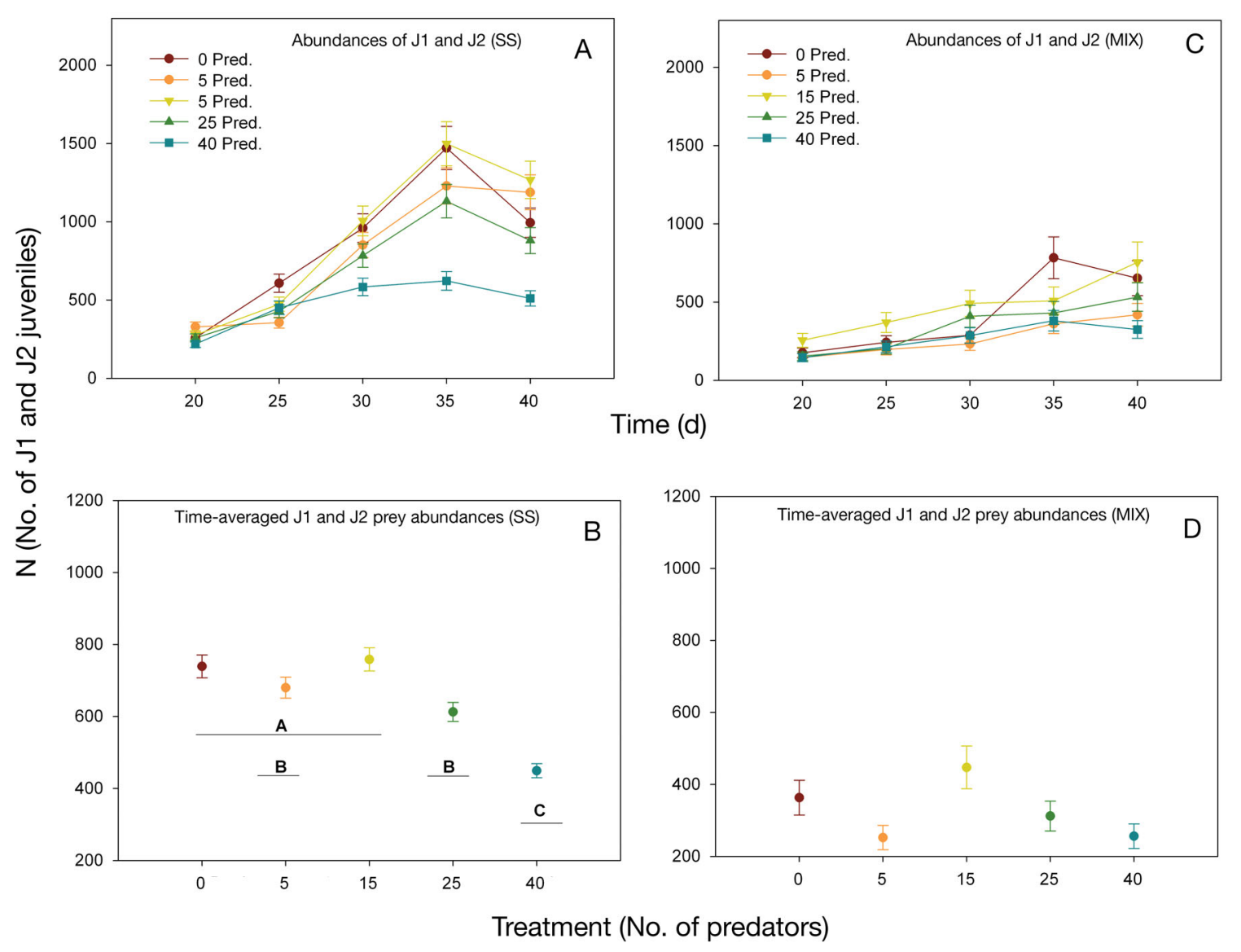

Fig. 3. Diplolaimelloides oschei. As in Fig. 1, but for J1 and J2 juveniles

significantly between treatments $(F=4.71$; p $<0.03)$ and treatments versus time $(F=3.83 ; \mathrm{p}<0.001)$, with controls yielding consistently higher densities than all other treatments. There was a general tendency of decreasing J1 and J2 densities with increasing predator abundance, but only the 40-predator treatment had significantly $(\mathrm{p}<0.02)$ lower abundances than the control (Fig. 4A,B). Abundances of D. meyli first- and second-stage juveniles in the mixed prey species experiment differed significantly between treatments $(F=$ 9.35; $\mathrm{p}<0.01)$ and between treatments versus time $(F=$ $4.28 ; \mathrm{p}<0.0001)$. These differences were again largely due to the highest predator abundance treatment, which yielded significantly lower prey abundances than the control, the 5-predator, and the 15-predator treatments ( $p<0.01$; Fig. 4C,D).

All main effects, and most of their interactions, on the abundance of early-stage juvenile prey nematodes were significant, except the interactions experiment versus treatment, prey versus treatment, and experiment versus prey versus treatment (Table S2 in the Supplement).

Abundances of early-stage juveniles were consistently lower in the MIX than in the SS experiment $(\mathrm{p}<$
0.001; Fig. S2A-C in the Supplement). The treatment effect generally increased with increasing predator abundance in both SS and MIX, albeit with few significant differences between treatments (Fig. S2C).

\section{Late-stage juveniles (J3, J4)}

Abundances of Diplolaimelloides oschei third- and fourth-stage juveniles (J3 and J4) in the SS experiment differed highly significantly between treatments $(F=$ 24.90; $\mathrm{p}<0.0001)$ and treatments versus time $(F=6.46$; $\mathrm{p}<0.001)$. Controls had higher J3 and J4 densities throughout the experiment, even though they started decreasing after Day 30. Overall, abundances of J3 and $\mathrm{J} 4$ did not differ significantly between predator treatments (Fig. 5A,B). Abundances of D. oschei J3 and $\mathrm{J} 4$ in the mixed prey species experiment differed significantly between treatments $(F=5.71 ; \mathrm{p}<0.01)$, and between treatments versus time $(F=2.08$; $\mathrm{p}<0.03)$. However, these differences were largely due to the higher initial abundances in the 15-predator treatment and the subsequent different temporal dynamics in this treatment (Fig. 5C,D). 


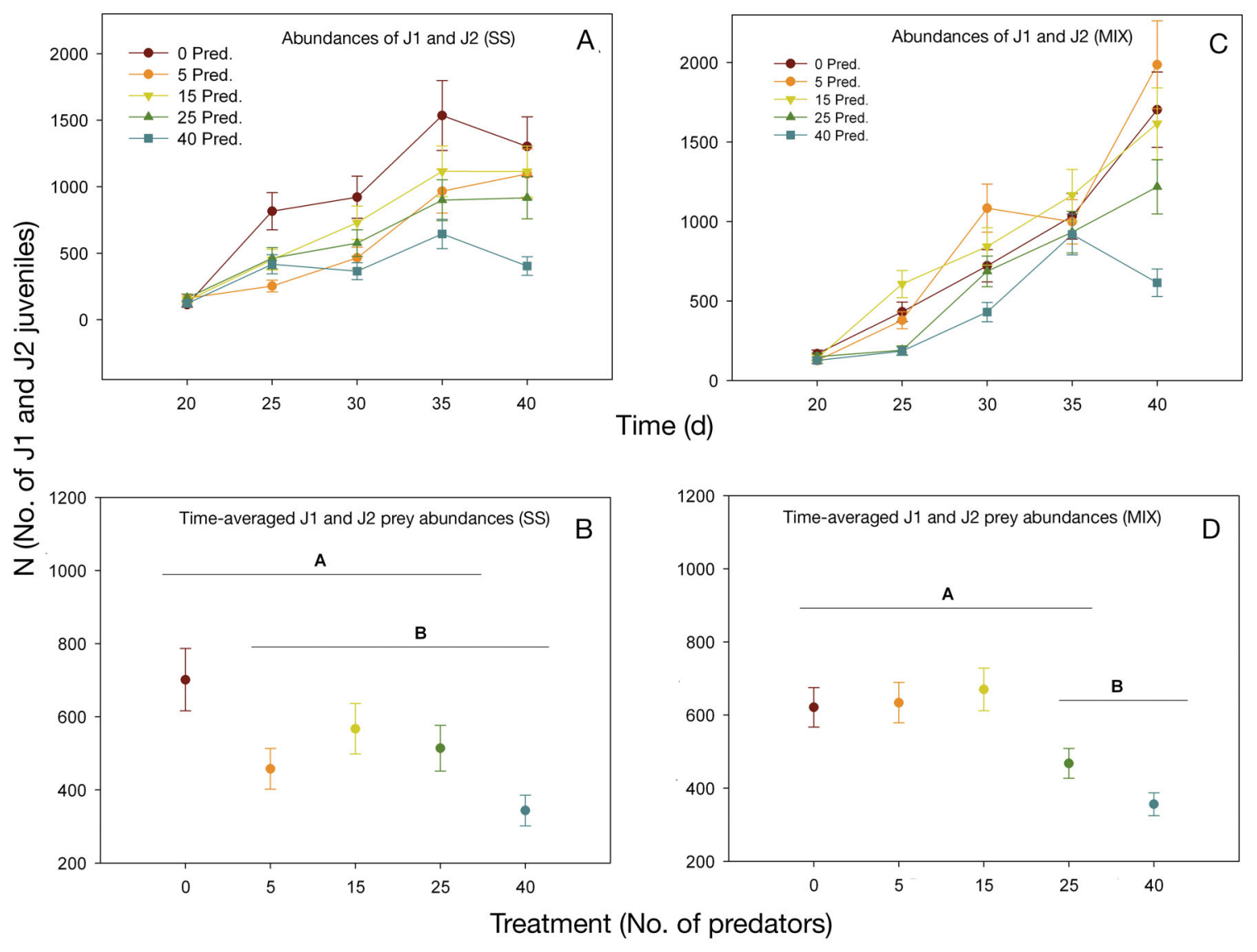

Fig. 4. Diplolaimelloides meyli. As in Fig. 1, but for J1 and J2 D. meyli juveniles

Abundances of Diplolaimelloides meyli third- and fourth-stage juveniles (J3 and J4) in the SS experiment differed highly significantly between treatments $(F=$ $7.70 ; \mathrm{p}<0.0001)$ and treatments versus time $(F=3.14$; $\mathrm{p}<0.01$ ). The control and the 5-predator treatment yielded on average significantly higher J3 and J4 densities than all other treatments. Lowest J3 and J4 abundances were found in the 2 highest predator abundance treatments (Fig. 6A,B). Abundances of D. meyli $\mathrm{J} 3$ and $\mathrm{J} 4$ in the mixed prey species experiment differed significantly between treatments $(F=8.10$; $\mathrm{p}<$ $0.01)$ and between treatments versus time $(F=2.26 ; \mathrm{p}<$ $0.03)$. The only significant pairwise difference between treatments, however, was that between the control and the 40-predator treatment ( $\mathrm{p}<0.05$; Fig. $6 \mathrm{C}, \mathrm{D})$.

All main effects and most of their interactions, except experiment versus prey versus treatment, on the abundance of J3 and J4 Diplolaimelloides were significant (Table S3 in the Supplement).

Abundances of J3 and J4 in the MIX experiment were significantly lower than in the SS experiment throughout time $(p<0.001)$, and this was also true when considering both prey species separately $(p<$
0.0001). There was a general tendency for J3 and J4 abundances to decrease with increasing abundance of predators in both experiments (except the 15-predator treatment in MIX), but with few significant differences (Fig. S3A-C in the Supplement).

\section{Adults}

Adult Diplolaimelloides oschei abundances in the SS experiment differed highly significantly between treatments $(F=77.45 ; \mathrm{p}<0.0001)$ and treatments versus time $(F=18.82 ; \mathrm{p}<0.0001)$. Abundances of adults in the control treatment peaked $5 \mathrm{~d}$ after the start of the predation trials as a result of full maturation of F1 progeny, and declined at the last count (see also dos Santos et al. 2008). All other treatments yielded lower adult abundances throughout the experiment, and most pairwise comparisons yielded significant differences ( $p<0.01$; Fig. 7A,B). D. oschei adult abundances in the MIX experiment differed highly significantly between treatments $(F=7.88 ; \mathrm{p}<0.01)$, and between treatments versus time $(F=2.70 ; \mathrm{p}<0.01)$. The control 


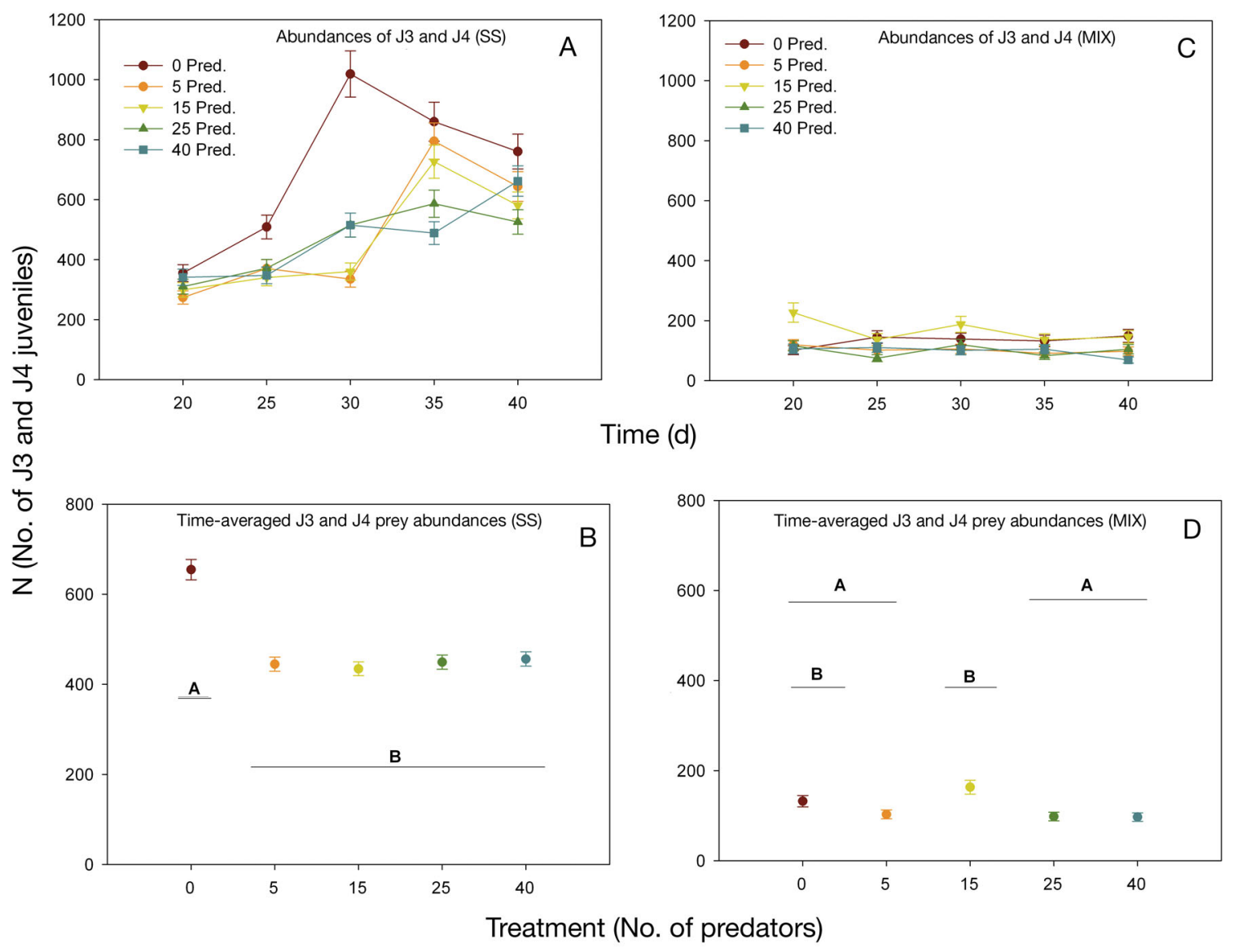

Fig. 5. Diplolaimelloides oschei. As in Fig. 1, but for J3 and J4 juveniles

treatment yielded the highest abundance of adults, increasing monotonously with time until $15 \mathrm{~d}$ after predator inoculation, followed by a slight decrease at the last count. All other treatments yielded lower adult prey abundances throughout the experiment, but with only few significant pairwise differences $(\mathrm{p}<0.02)$.

Adult Diplolaimelloides meyli abundances in the SS experiment differed highly significantly between treatments $(F=48.54 ; \mathrm{p}<0.0001)$ and treatments versus time $(F=17.06 ; \mathrm{p}<0.0001)$. Increasing predator densities yielded decreasing adult prey abundances (Fig. 8A,B). D. meyli adult abundances in the MIX experiment differed significantly between treatments $(F=33.47 ; \mathrm{p}<0.0001)$ and between treatments versus time $(F=7.42 ; \mathrm{p}<0.0001)$. As in the SS experiment, there was a progressive decrease in adult prey abundances with increasing predator abundance (Fig. 8C,D).

All main effects and their interactions, except that between experiment versus prey versus treatment, exhibited significant effects on abundances of adult prey nematodes (Table S4 in the Supplement).

Abundances of adult prey did not differ between the SS and MIX experiments, although prey abundances in the SS experiment were initially (first 2 counts) higher but ended lower than in the MIX experiment. In both experiments, adult prey abundances generally decreased with increasing predator abundance (Fig. S4A-C in the Supplement).

\section{DISCUSSION}

\section{Predator control over prey population development}

While many meiobenthic taxa are considered predators, facultative predators, or omnivores (Coull 1973, Watzin 1985, Moens \& Vincx 1997), the importance of predation among meiobenthos is poorly known. Nematode trophic position is usually inferred from stoma structure (Wieser 1953, Moens et al. 2004), even though observational studies have demonstrated discrepancies between mouth morphology and feeding habits, as well as flexibility in feeding behavior (Romeyn \& Bouwman 1983, Moens \& Vincx 1997). The main question therefore is whether the predation rates of supposedly predatory nematodes are sufficient to exert predator control over prey assemblages. High 


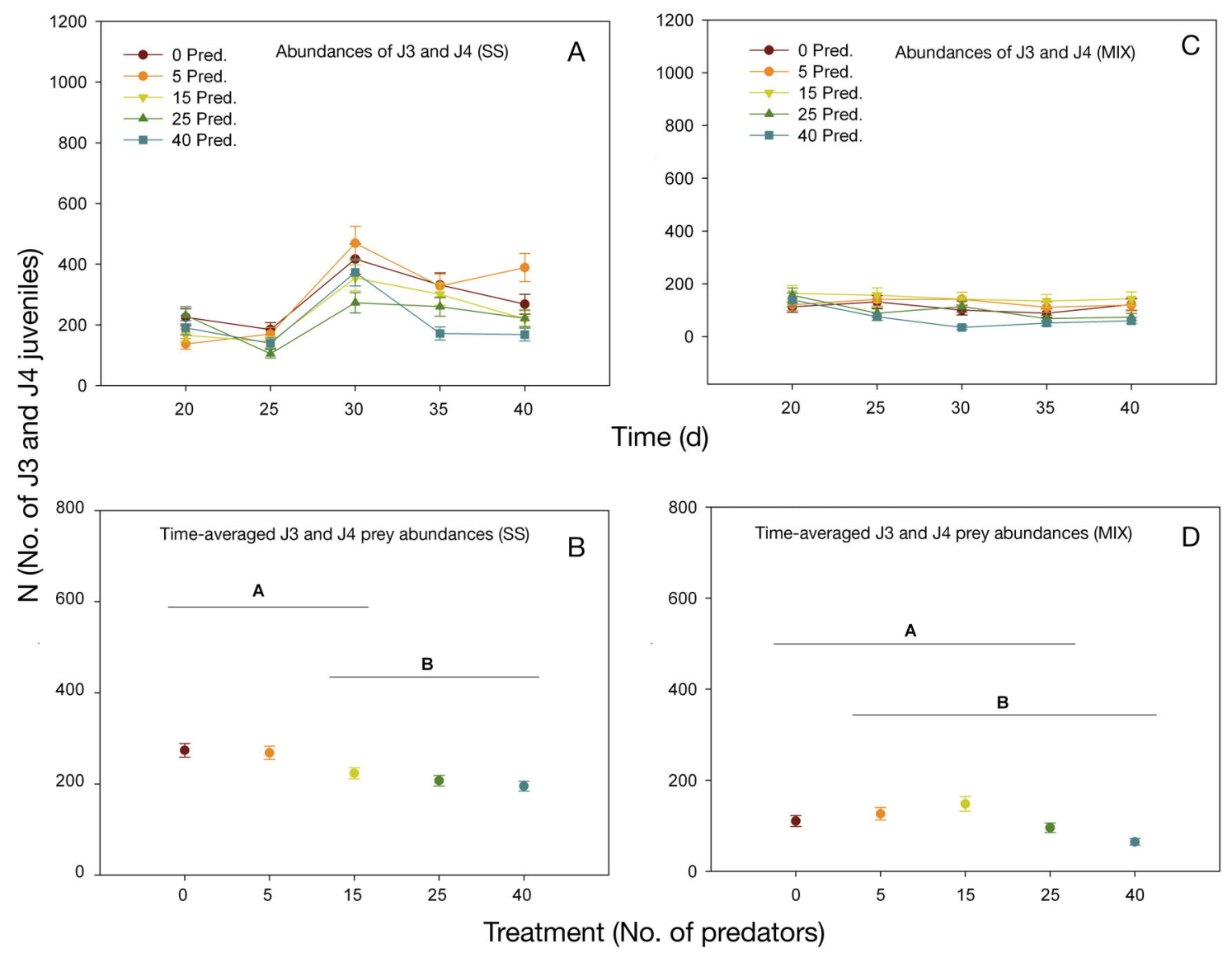

Fig. 6. Diplolaimelloides meyli. As in Fig. 1, but for J3 and J4 D. meyli juveniles

predation rates of predacious nematodes on nematode prey in laboratory experiments have been reported for several terrestrial and/or freshwater species (Yeates 1969, Bilgrami \& Jairajpuri 1989, Khan et al. 1991, Bilgrami \& Gaugler 2005, Bilgrami et al. 2005), as well as for the marine species Enoploides longispiculosus and Adoncholaimus fuscus (Moens et al. 2000, Hamels et al. 2001, Gallucci et al. 2005). With the exception of a few studies on the control of plant-parasitic nematodes (Khan \& Kim 2007 and references therein), we are unaware of any studies which have looked at population-level responses of prey nematodes to predation. Our data show a clear effect of the predatory nematode Enoploides over the population development of both monhysterid prey species used in this experiment, with a general reduction in prey abundance with increasing predator densities. The effect is initially only pronounced for adult prey, but over time this effect will culminate in a lower reproduction at the population level (less reproductive adults present) and hence in a slower overall population development (see Fig. S5 in the Supplement). This is in accordance with the clear negative correlation between densities of Enoploides and of prey nematodes in sediments at the field site where Enoploides were collected for our experiments (Gallucci et al. 2005). The observed effect was smaller than what we could have expected based on the predation rates found in short-term experiments (24 to 48 h; e.g. Moens et al. 2000). There may be several reasons for this: (1) agar may not be an optimal medium for Enoploides, which is very sensitive to the matrix in which it forages (Gallucci et al. 2005). However, in short-term experiments, predation rates on agar were very similar to those in sediments (Gallucci et al. 2005). Moreover, we observed very little predator mortality in our experiments and, for the first time, obtained reproduction of Enoploides in laboratory microcosms, suggesting that our experimental conditions were favorable. (2) Predators could have been partially feeding on bacterial food, as demonstrated for some predacious nematodes from soil (Yeates 1969, 1987). However, Moens et al. (1999) found no measurable bacteria uptake by Enoploides. (3) Rates of short-term experiments may yield overestimates as a result of preexperimental conditions (e.g. starvation). However, the studies we have referred to always used freshly collected and non-starved predators, as we did in the present experiments. Moreover, observations of gut con- 


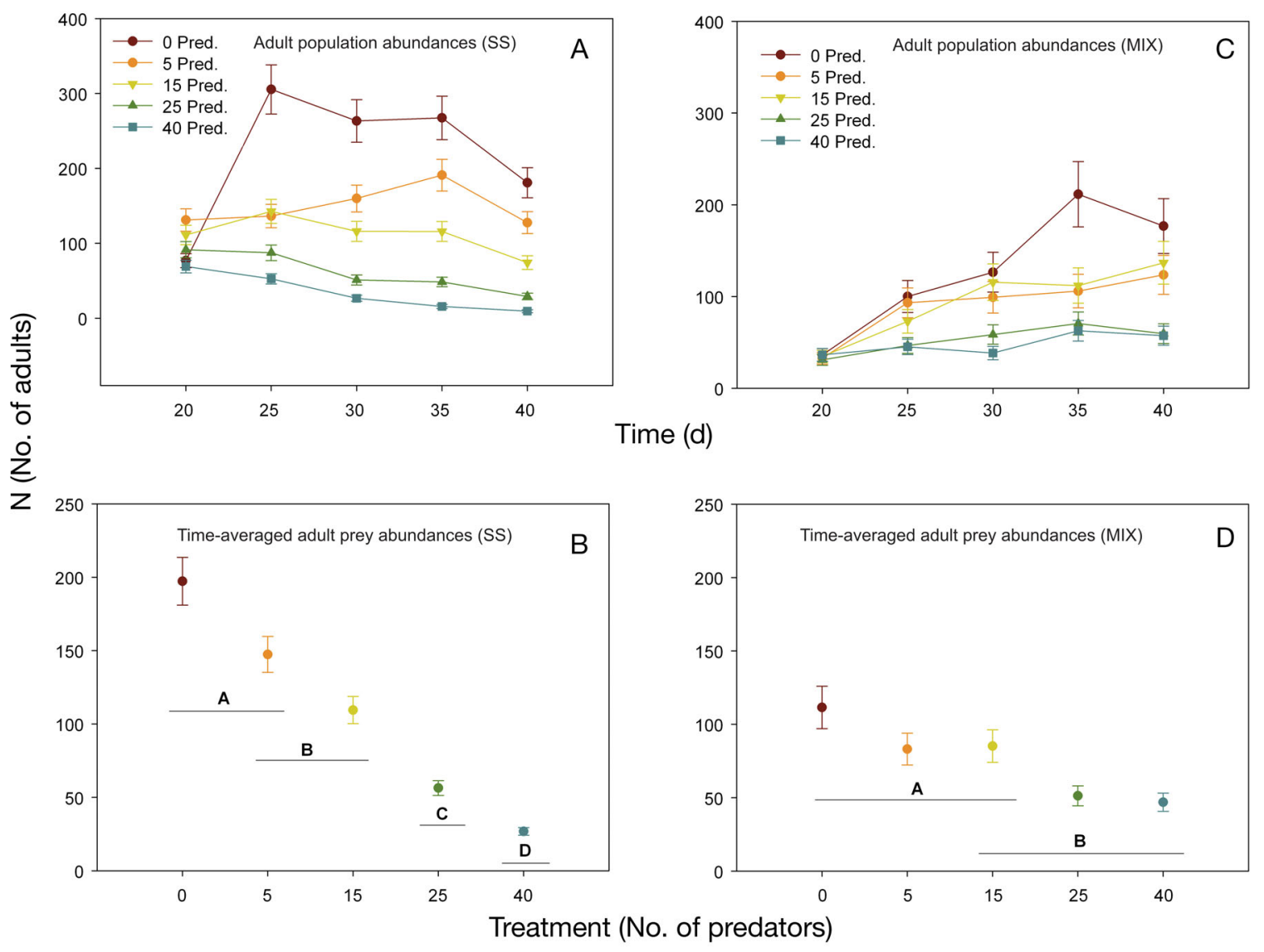

Fig. 7. Diplolaimelloides oschei. As in Fig. 1, but for adults only

tents suggest that at least some predacious nematodes have considerably higher predation rates in the field (Fonseca \& Gallucci 2008). (4) Predator functional responses (see 'Size-selective predation and predator functional response allow prey populations to persist'). (5) Finally, negative density-dependent effects among predators in the higher predator abundance treatments (Hamels et al. 2001) may have affected the magnitude of the predatory effect in the treatments with high predator abundances.

The existence of a clear functional response for Enoploides at prey densities in the range of adult prey densities in our experiments (Moens et al. 1999) implies that the somewhat higher prey abundances in the MIX experiment could have caused higher per capita predation rates. Hence, while we attribute the lower than expected prey abundances in the MIX experiment to inhibitory interactions between both prey species, predator functional response may also have contributed. However, we consider it unlikely that this effect was important. (1) The densities of adult prey in the control treatment of the present experiment $25 \mathrm{~d}$ after inoculation of the Diplolaimelloides species exceeded the prey densities at which optimal predation rates of
Enoploides are obtained (ca. 50 prey ml ${ }^{-1}$; Moens et al. 1999), averaging $100 \pm 25$ and $125 \pm 25$ ind. $\mathrm{ml}^{-1}$ in the MIX and SS experiment, respectively. (2) Because of the relatively small difference in overall adult prey abundance in the MIX and SS experiment, we are confident that per capita predation rates of Enoploides did not substantially differ between both experiments as a result of the predator functional response.

\section{Size-selective predation and predator functional response allow prey populations to persist}

Based upon per capita predation rates obtained in laboratory microcosm experiments, Moens et al. (2000) suggested that in fine to medium sandy sediments, Enoploides could drive prey populations to extinction. However, the low efficiency of predation at low prey densities may provide a window of opportunity for prey to avoid extinction. The functional response described for Enoploides feeding on monhysterid prey implies that this predator requires relatively high prey densities for optimal predation rates (Moens et al. 2000). The densities of adult prey in the control treat- 


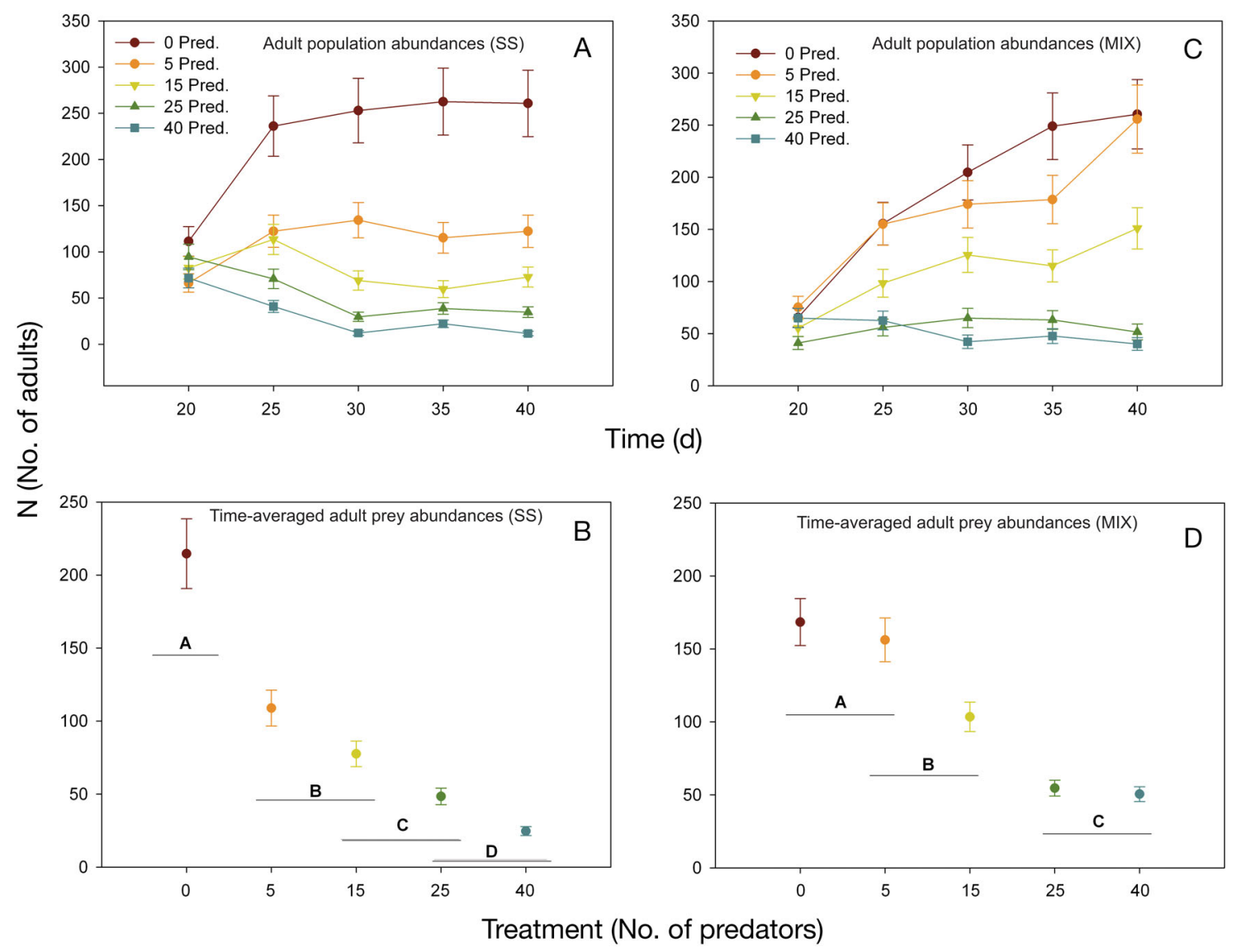

Fig. 8. Diplolaimelloides meyli. As in Fig. 1, but for adult D. meyli only

ment of the present experiment approached optimal densities $25 \mathrm{~d}$ after inoculation of the Diplolaimelloides species. In the predation treatments, the increase in adult prey observed in the controls between Days 20 and 25 was largely or completely removed by predation, keeping adult prey densities well below those expected to yield optimal predation rates. Prey availability, then, also depends on the extent to which juvenile nematodes are suitable prey to Enoploides. Our study clearly shows that small juveniles (J1 and J2) are unsuitable as prey. The differences in abundance of J1 and J2 Diplolaimelloides between different treatments tend to increase at the end of the experiment, which is a result of lowered abundances of adult prey producing offspring rather than of J1 and J2 being removed by predation. The lower time-averaged abundances of $\mathrm{J} 1$ and $\mathrm{J} 2$ at the 2 highest predator densities therefore did not result from direct predation on juveniles, but from a strong predatory control over adult abundance and hence over the rate of population increase. Moreover, we observed many encounters of predators with small juveniles, and these consistently remained without a predator-prey interaction. Abundances of J3 and J4 juvenile prey were significantly affected by preda- tion, but with limited dependence on predator abundance, suggesting that these nematode life stages are vulnerable to predation by Enoploides, but to a lesser extent than adults. It is plausible that this 'selective predation' is caused by size-selective feeding. Size is a common food selection criterion in meiofaunal organisms grazing bacteria (Salinas et al. 2007) or microphytobenthos (Moens \& Vincx 1997, De Troch et al. 2006). However, size-dependent predation was not considered an important driver for the selective predation on different prey nematode species observed in a previous study with Enoploides, which contended that encounter probabilities together with the capacity of prey species for vigorous escape movements were the dominant drivers of selectivity (Moens et al. 2000). Indirectly, however, prey size may be generally more relevant because larger nematodes tend to be more mobile (Gallucci et al. 2008) and hence will have higher encounter probabilities. On the other hand, larger-sized prey may also have a better capacity to escape upon predator attack. We have no indications, however, that the prey species used in our experiments frequently manage to escape from predator attack, or that escape success would differ according to prey size. In any 
case, the selection against (small) juvenile prey nematodes observed in the present study provides another mechanism through which prey nematode populations may avoid extinction at high predator densities. Size selectivity, in combination with a strong functional response and negative abundance-dependent effects among the predators (Hamels et al. 2001) may thus allow prey populations to survive under conditions of high predator abundance. Habitat (sediment) structure further adds to this, since it has been shown that even modest increases in silt content and changes in grain size profoundly affect the predation rates of $E$. longispiculosus (Gallucci et al. 2005), which leads us to hypothesize that small-scale spatial heterogeneity in sediment texture may create refuges in which prey are not, or less, vulnerable to predation by Enoploides. If so, we could expect that in sediments with high predator abundance, there would be many prey species occurring at very low adult densities. If small juvenile nematodes would more generally be less susceptible to predation by other nematodes, one could expect to find higher proportions of small juvenile prey nematodes in samples with a high relative abundance of predators. There is currently little evidence for this, but perhaps this is due to sampling bias, smaller juveniles having a high chance of passing through the mesh sizes typically used in meiobenthic research (de Bovée et al. 1974, T. Moens unpubl.). Nevertheless, gut content analysis of the large nematode Pontonema sp. from Arctic deep-sea sites suggests that this predator preferentially preys on small-sized nematode prey (Fonseca \& Gallucci 2008). Hence, we must be extremely careful when making generalizations from studies on single model species.

\section{Predation alleviates horizontal interactions between prey nematode species}

In short-term ( 24 to $48 \mathrm{~h}$ ) incubations with both prey species together, Enoploides showed a clear preference for Diplolaimelloides oschei over its congener D. meyli (Gallucci et al. 2005). In combination with the inhibitory interactions among both prey species (De Mesel et al. 2006, dos Santos et al. 2009), we expected predation to further emphasize the dominance of $D$. meyli over D. oschei in the MIX experiment. D. oschei indeed attained lower abundances than its congener in the MIX experiment, whereas it was equally or even slightly more abundant than $D$. meyli in the SS experiment. At first glance, this is in agreement with the above-mentioned prey preference of Enoploides. However, when looking at individual treatments, perhaps the strongest discrepancy in D. oschei abundances between the SS and MIX exper- iment occurred in the controls without predators. Here, $D$. oschei in the MIX experiment attained numbers only half to a third of those in the SS experiment. Moreover, $D$. oschei abundances before predator inoculation were considerably lower in all treatments of the MIX experiment than in the SS experiment. D. meyli also exhibited lower numbers, particularly of adults, in the controls of the MIX experiment and prior to predator inoculation in all other treatments, but the difference was far less pronounced than in $D$. oschei. This is undoubtedly due to the above-mentioned inhibitory interactions among closely related Monhysteridae and between other 'confunctional' (i.e. belonging to the same trophic guild) nematodes (Mikola 1998, IlievaMakulec 2001, Postma-Blaauw et al. 2005, De Mesel et al. 2006, dos Santos et al. 2009). The mechanism behind this inhibitory interaction remains unclear, but simple competition for food or space is unlikely to be the principal cause (De Mesel et al. 2006, dos Santos et al. 2009). The present results further indicate that these inhibitory interactions tend to be asymmetric, with a strong negative effect of $D$. meyli on $D$. oschei and a much weaker reverse effect. This is in agreement with Mikola (1998), Postma-Blaauw et al. (2005), and De Mesel et al. (2006), but contrasts with dos Santos et al. (2009). The latter study, however, included a third bacterial-feeding nematode species, the presence of which likely affected the mutual interaction between both Diplolaimelloides species (cf. Levine 1999).

In contrast to our expectation that predation would emphasize dominance of Diplolaimelloides meyli over $D$. oschei, increasing predation intensity rather relieved the inhibitory pressure of $D$. meyli on $D$. oschei. Particularly in the 2 treatments with the highest predator abundances, D. oschei abundances in the MIX experiment were equal to, or even exceeded, those in the SS experiment. There are several possible explanations for this phenomenon. First, if the inhibitory effect of 1 species over another is abundance dependent, then the lowered prey abundances, particularly at high predator abundance, may alleviate this effect. Abundance-dependent inhibition has been reported as an important feature of both pre- and post-settlement interactions between larvae of soft-sediment depositand suspension-feeding macrobenthos (Olafsson et al. 1994). Inhibition between both monhysterid species used in our experiments was most pronounced at food availabilities allowing optimal population growth and less so at suboptimal food levels (dos Santos et al. 2009), indicating that abundance dependence may indeed play a role. One unexpected side effect is that while predation generally resulted in a continuous decrease of prey abundance with time in our SS experiment, there was a small but steady increase in prey 
abundance with time in the 2-species experiment. Hence, the overall effect of predation on the prey assemblage in the MIX experiment was at least as strongly determined by indirect effects as by direct predation pressure, a feature which has repeatedly been found in assemblages with prominent horizontal interactions, be they competitive, facilitative, or inhibitory (Abrams \& Matsuda 1996, Berger et al. 2001, Hebblewhite et al. 2005, Gross 2008).

Alternatively, predation is often more intense on competitively dominant species than on rarer or inferior species, releasing competitively inferior prey from suppression by that dominant species (Wootton 1992, Austen \& Widdicombe 1998, Schratzberger \& Warwick 1999, Navarrete \& Castilla 2003). Applied to the present study, the predatory effect of Enoploides on Diplolaimelloides meyli decreased the inhibitory effect of that species on $D$. oschei.

The interaction chain observed in the present study was very pronounced, in accordance with the idea that interaction chains tend to be stronger in aquatic than in terrestrial systems (Shurin et al. 2002). However, interaction chains are expected to be stronger in assemblages of low complexity (Polis \& Strong 1996, Shurin et al. 2002). Nematode assemblages tend to be characterized by high local diversity and are susceptible to predation by a range of predators. Hence, there is an urgent need for studies on more diverse and complex assemblages to assess to what extent the present results can be translated to natural systems other than decomposing macrophyte detritus, or - in terrestrial systems - organically enriched soil patches, which are often characterized by a low nematode diversity (Warwick 1987, Wang et al. 2004, Ferris \& Bongers 2006). There is also a need to address the impact of habitat structural complexity, because both the predation efficiency of, and the horizontal interactions between, nematode species may differ in natural sediments compared to the more simple and homogeneous agar matrix used in the present study.

\section{CONCLUSIONS}

Our study has demonstrated that predation by abundant predatory meiofauna is likely to exert significant predatory effects on prey nematode populations. Even under high predation pressure, however, prey populations are unlikely to be driven to extinction, as - in addition to previously reported spatial and temporal refuges - size-selective predation and low predation efficiency at low prey densities should allow prey populations to persist, albeit with a different age and size structure. The longer-term stability of such simple 1 predator-1 prey species systems remains to be deter- mined. Extrapolation of these results to assemblages with more than 1 prey species have to be made with extreme caution, since the outcome of the predatory effect then not only depends on direct predatorinduced mortality, but also on the degree to which predation modifies the strength of horizontal interactions between prey species. Finally, we have previously shown the population dynamics in, and interactions between, the prey species used here to be strongly affected by food availability. Hence, integration of predator-prey dynamics with resource effects on within-guild diversity and assemblage structure may well yield even more complex assemblage patterns (Worm et al. 2002).

Acknowledgements. This work was financially supported by a Coordenação de Aperfeiçoamento de Pessoal de Nível Superior (CAPES) grant to G.A.P.S., by Ghent University through BOF projects 0110600002 and 01GZ0705, and by the Flemish Fund for Scientific Research FWO through project G.0192.09. G.A.P.S. is grateful to Y. Valdés Vázquez for help and support during the nematode counts. F. Hendrickx and S. Derycke provided invaluable advice on the statistical analyses. We also acknowledge 4 anonymous referees for their valuable comments on a previous version of our manuscript.

\section{LITERATURE CITED}

Abrams PA, Matsuda H (1996) Positive indirect effects between prey species that share predators. Ecology 77 : 610-616

Ambrose WG Jr (1984a) Influences of predatory polychaetes and epibenthic predators on the structure of a soft-bottom community in a Maine estuary. J Exp Mar Biol Ecol 81: $115-145$

Ambrose WG Jr (1984b) Role of predatory infauna in structuring marine soft-bottom communities. Mar Ecol Prog Ser 17:109-115

Ambrose WG Jr (1984c) Increased emigration of the amphipod Rhepoxynius abronius (Barnard) and the polychaete Nephtys caeca (Fabricius) in the presence of invertebrate predators. J Exp Mar Biol Ecol 80:67-75

Ambrose WG Jr (1991) Are infaunal predators important in structuring marine soft-bottom communities? Am Zool 31: 849-860

Austen M, Widdicombe S (1998) Experimental evidence of effects of the heart urchin Brissopsis lyrifera on associated subtidal meiobenthic nematode communities. J Exp Mar Biol Ecol 222:219-238

Baden SP, Boström C (2001) The leaf canopy of seagrass beds: faunal community structure and function in a salinity gradient along the Swedish coast. In: Reise K (ed) Ecological comparisons of sedimentary shores. Ecological studies, Vol 151. Springer-Verlag, Berlin, p 213-231

Bell S, Coull B (1978) Field evidence that shrimp predation regulates meiofauna. Oecologia 35:141-148

Berger J, Stacey PB, Bellis L, Johnson MP (2001) A mammalian predator-prey imbalance: grizzly bear and wolf extinction affect avian neotropical migrants. Ecol Appl 11: 947-960

> Beukema J, Dekker R (2005) Decline of recruitment success in cockles and other bivalves in the Wadden Sea: possible 
role of climate change, predation on postlarvae and fisheries. Mar Ecol Prog Ser 287:149-167

Bilgrami AL, Gaugler R (2005) Feeding behaviour of the predatory nematodes Laimydorus baldus and Discolaimus major (Nematoda: Dorylaimida). Nematology 7:11-20

Bilgrami AL, Jairajpuri MS (1989) Resistance of prey to predation and strike rate of the predators, Mononchoides longicaudatus and $M$. fortidens (Nematoda: Diplogasterida). Rev Nematol 12:45-49

Bilgrami A, Gaugler R, Brey C (2005) Prey preference and feeding behaviour of the diplogastrid predator Mononchoides gaugleri (Nematoda: Diplogastrida). Nematology 7:333-342

> Chassot E, Gascuel D, Colomb A (2005) Impact of trophic interactions on production functions and on the ecosystem response to fishing: a simulation approach. Aquat Living Resour 18:1-13

Commito J, Ambrose WG Jr (1985) Multiple trophic levels in soft-bottom communities. Mar Ecol Prog Ser 26:289-293

> Connolly SR, Roughgarden J (1999) Theory of marine communities: competition, predation, and recruitment-dependent interaction strength. Ecol Monogr 69:277-296

Coull BC (1973) Estuarine meiofauna: a review: trophic relationships and microbial interactions. In: Stevenson LH, Colwell RR (eds) Estuarine microbial ecology. University of South Carolina Press, Columbia, SC, p 499-511

Cury P, Shannon L, Shin YJ (2003) The functioning of marine ecosystems: a fisheries perspective. In: Sinclair M, Valdimarsson $G$ (eds) Responsible fisheries in the marine ecosystem. CAB International, Wallingford, p 103-123

de Bovée F, Soyer J, Albert P (1974) The importance of the mesh size for the extraction of the muddy bottom meiofauna. Limnol Oceanogr 19:350-354

> De Mesel I, Derycke S, Swings J, Vincx M, Moens T (2006) Role of nematodes in decomposition processes: Does within-trophic group diversity matter? Mar Ecol Prog Ser 321:157-166

De Troch M, Chepurnov V, Gheerardyn H, Vanreusel A, Olafsson E (2006) Is diatom size selection by harpacticoid copepods related to grazer body size? J Exp Mar Biol Ecol 332:1-11

> Desroy N, Retière C, Thiébaut E (1998) Infaunal predation regulates benthic recruitment: an experimental study of the influence of the predator Nephtys hombergii (Savigny) on recruits of Nereis diversicolor (OF Müller). J Exp Mar Biol Ecol 228:257-272

Dietrich G, Kalle K (1957) Allgemeine Meereskunde. Gebrüder Borntraeger, Berlin

dos Santos GAP, Derycke S, Genevois VGF, Coelho L, Correia MTS, Moens T (2008) Differential effects of food availability on population growth and fitness of three species of estuarine, bacterial-feeding nematodes. J Exp Mar Biol Ecol 355:27-40

dos Santos GAP, Derycke S, Genevois VGF, Coelho LCBB, Correia MTS, Moens T (2009) Interactions among bacterial-feeding nematode species at different levels of food availability. Mar Biol 156:629-640

Ferris H, Bongers T (2006) Nematode indicators of organic enrichment. J Nematol 38:3-12

Fonseca G, Gallucci F (2008) Direct evidence of predation in deep-sea nematodes: the case of Pontonema sp. Cah Biol Mar 49:295-297

Frank KT, Petrie B, Choi JS, Leggett WC (2005) Trophic cascades in a formerly cod-dominated ecosystem. Science 308:1621-1623

> Gallucci F, Steyaert M, Moens T (2005) Can field distributions of marine predacious nematodes be explained by sedi- ment constraints on their foraging success? Mar Ecol Prog Ser 304:167-178

Gallucci F, Moens T, Vanreusel A, Fonseca G (2008) Active colonization of disturbed sediments by deep-sea nematodes: evidence for the patch mosaic model. Mar Ecol Prog Ser 367:173-183

Gascuel D (2005) The trophic-level based model: a theoretical approach of fishing effects on marine ecosystems. Ecol Model 189:315-332

Gross K (2008) Positive interactions among competitors can produce species-rich communities. Ecol Lett 11:929-936

Gruner DS, Smith JE, Seabloom EW, Sandin SA and others (2008) A cross-system synthesis of consumer and nutrient resource control on producer biomass. Ecol Lett 11: $740-755$

> Hairston NG, Smith FE, Slobodkin LB (1960) Community structure, population control, and competition. Am Nat 94: 421-425

Hamels I, Moens T, Muylaert K, Vyverman W (2001) Trophic interactions between ciliates and nematodes from an intertidal flat. Aquat Microb Ecol 26:61-72

> Hassell MP, May RM (1986) Generalist and specialist natural enemies in insect predator-prey interactions. J Anim Ecol 55:923-940

> Hebblewhite M, White CA, Nietvelt CG, McKenzie JA and others (2005) Human activity mediates a trophic cascade caused by wolves. Ecology 86:2135-2144

Heip C, Vincx M, Vranken G (1985) The ecology of marine nematodes. Oceanogr Mar Biol Annu Rev 23:399-489

Ilieva-Makulec K (2001) A comparative study of the life strategies of two bacterial-feeding nematodes under laboratory conditions. III. Influence of the initial nematode density on the interactions of Arobeloides nanus (de Man 1880) Anderson and Dolichorhabditis dolichura (Schneider 1866) Andrassy 1983 in mixed cultures. Pol J Ecol 49:137-144

Ives AR, Cardinale BJ, Snyder WE (2005) A synthesis of subdisciplines: predator-prey interactions, and biodiversity and ecosystem functioning. Ecol Lett 8:102-116

Kennedy AD (1994) Predation within meiofaunal communities: description and results of a rapid-freezing method of investigation. Mar Ecol Prog Ser 114:71-79

Khan Z, Kim YH (2005) The predatory nematode, Mononchoides fortidens (Nematoda: Diplogasterida), suppresses the root-knot nematode, Meloidogyne arenaria, in potted field soil. Biol Control 35:78-82

- Khan Z, Kim YH (2007) A review on the role of predatory soil nematodes in the biological control of plant parasitic nematodes. Appl Soil Ecol 35:370-379

Khan Z, Bilgrami AL, Jairajpuri MS (1991) Some observations on the predation ability of Aporcelaimellus nivalis (Altherr, 1952) Heyns 1966 (Nematoda: Dorylaimida). Nematologica 37:333-342

Levine JM (1999) Indirect facilitation: evidence and predictions from a riparian community. Ecology 80:1762-1769

Menge BA (2000) Top-down and bottom-up community regulation in marine rocky intertidal habitats. J Exp Mar Biol Ecol 250:257-289

Mikola J (1998) Effects of microbivore species composition and basal resource enrichment on trophic-level biomasses in an experimental microbial-based soil food web. Oecologia 117:396-403

> Mikola J, Setälä H (1998) No evidence of trophic cascades in an experimental microbial-based soil food web. Ecology 79:153-164

> Moens T, Vincx M (1997) Observations on the feeding ecology of estuarine nematodes. J Mar Biol Assoc UK 77:211-227

Moens T, Vincx M (1998) On the cultivation of free-living 
marine and estuarine nematodes. Helgol Meersunters 52: 115-139

Moens T, Vincx M (2000a) Temperature and salinity constraints on the life cycle of two brackish-water nematode species. J Exp Mar Biol Ecol 243:115-135

Moens T, Vincx M (2000b) Temperature, salinity and food thresholds in two brackish-water bacterivorous nematode species: assessing niches from food absorption and respiration experiments. J Exp Mar Biol Ecol 243:137-154

Moens T, Verbeeck L, Vincx M (1999) Feeding biology of a predatory and a facultatively predatory nematode (Enoploides longispiculosus and Adoncholaimus fuscus). Mar Biol 134:585-593

> Moens T, Herman P, Verbeeck L, Steyaert M, Vincx M (2000) Predation rates and prey selectivity in two predacious estuarine nematode species. Mar Ecol Prog Ser 205: 185-193

Moens T, Yeates G, De Ley P (2004) Use of carbon and energy sources by nematodes. In: Cook R, Hunt DJ (eds) 4th Int Congr Nematol. Nematology Monographs and Perspectives, Tenerife, p 529-545

Moens T, Bouillon S, Gallucci F (2005) Dual stable isotope abundances unravel trophic position of estuarine nematodes. J Mar Biol Assoc UK 85:1401-1407

> Murdoch WW, Briggs CJ (1996) Theory for biological control: recent developments. Ecology 77:2001-2013

Navarrete S, Castilla J (2003) Experimental determination of predation intensity in an intertidal predator guild: dominant versus subordinate prey. Oikos 100:251-262

> Nelmes AJ (1974) Evaluation of the feeding behaviour of Prionchulus punctatus (Cobb), a nematode predator. J Anim Ecol 43:553-565

Olafsson E (2003) Do macrofauna structure meiofauna assemblages in marine soft-bottoms? Vie Milieu 53:249-265

Olafsson E, Peterson C, Ambrose W Jr (1994) Does recruitment limitation structure populations and communities of macro-invertebrates in marine soft sediments: the relative significance of pre-and post-settlement processes. Oceanogr Mar Biol Annu Rev 32:65-110

Paine RT (1966) Food web complexity and species diversity. Am Nat 100:65-75

Polis G, Strong D (1996) Food web complexity and community dynamics. Am Nat 147:813-846

Posey MH, Powell CM, Cahoon LB, Lindquist DG (1995) Topdown vs bottom up control of benthic community composition on an intertidal tideflat. J Exp Mar Biol Ecol 185:19-31

Posey MH, Alphin TD, Cahoon LB, Lindquist DG, Mallin MA, Nevers MB (2002) Top-down versus bottom-up limitation in benthic infaunal communities: direct and indirect effects. Estuar Coasts 25:999-1014

Posey MH, Alphin TD, Harwell H, Allen B (2005) Importance of low salinity areas for juvenile blue crabs, Callinectes sapidus Rathbun, in river-dominated estuaries of southeastern United States. J Exp Mar Biol Ecol 319:81-100

Postma-Blaauw MB, de Vries FT, de Goede RGM, Bloem J, Faber JH, Brussaard L (2005) Within-trophic group interactions of bacterivorous nematode species and their effects on the bacterial community and nitrogen mineralization. Oecologia 142:428-439

Reise K (1985) Tidal flat ecology: an experimental approach to species interactions, Vol 54. Springer, Berlin

Romeyn K, Bouwman L (1983) Food selection and consumption by estuarine nematodes. Neth J Aquat Ecol 17: 103-109

Rzeznik-Orignac J, Boucher G, Fichet D, Richard P (2008) Stable isotope analysis of food source and trophic position of intertidal nematodes and copepods. Mar Ecol Prog Ser

Editorial responsibility: Paul Snelgrove,

St. John's, Newfoundland, Canada
359:145-150

Salinas K, Edenborn S, Sexstone A, Kotcon J (2007) Bacterial preferences of the bacterivorous soil nematode Cephalobus brevicauda (Cephalobidae): effect of bacterial type and size. Pedobiologia 51:55-64

- Schratzberger M, Warwick RM (1999) Impact of predation and sediment disturbance by Carcinus maenas (L.) on free-living nematode community structure. J Exp Mar Biol Ecol 235:255-271

Shurin J, Borer E, Seabloom E, Anderson K and others (2002) A cross-ecosystem comparison of the strength of trophic cascades. Ecol Lett 5:785-791

> Steyaert M, Herman PMJ, Moens T, Widdows J, Vincx M (2001) Tidal migration of nematodes on an estuarine tidal flat (the Molenplaat, Schelde Estuary, SW Netherlands). Mar Ecol Prog Ser 224:299-304

Strasser M (2002) Reduced epibenthic predation on intertidal bivalves after a severe winter in the European Wadden Sea. Mar Ecol Prog Ser 241:113-123

> Sutherland TF, Shepherd PCF, Elner RW (2000) Predation on meiofaunal and macrofaunal invertebrates by western sandpipers (Calidris mauri): evidence for dual foraging modes. Mar Biol 137:983-993

Vander Zanden MJV, Essington TE, Vadeboncoeur Y (2005) Is pelagic top-down control in lakes augmented by benthic energy pathways? Can J Fish Aquat Sci 62:1422-1431

Vanfleteren JR (1980) Nematodes as nutritional models. In: BM Zuckermann (ed) Nematodes as biological models: aging and other model systems, Vol 2. Academic Press, New York, NY, p 47-79

Wall D, Moore J (1999) Interactions underground: soil biodiversity, mutualism, and ecosystem processes. Bioscience 49:109-117

> Wang K, McSorley R, Marshall A, Gallaher R (2004) Nematode community changes associated with decomposition of Crotalaria juncea amendment in litterbags. Appl Soil Ecol 27:31-45

Warwick R (1987) Meiofauna: their role in marine detrital systems. In: Moriarty DJW, Pullin RSV (eds) Proc Conf Detrital Systems for Aquaculture, Vol 14. The WorldFish Center, International Center for Living Aquatic Resources Management, Manila, p 282-295

Watzin MC (1983) The effects of meiofauna on settling macrofauna: meiofauna may structure macrofaunal communities. Oecologia 59:163-166

$>$ Watzin MC (1985) Interactions among temporary and permanent meiofauna: observations on the feeding and behavior of selected taxa. Biol Bull (Woods Hole) 169:397-416

Wieser W (1953) Die Beziehung zwischen Mundhöhlengestalt, Ernährungsweise und Vorkommen bei freilebenden marinen Nematoden. Ark Zool 4:439-484

> Wilson WH (1990) Competition and predation in marine softsediment communities. Annu Rev Ecol Syst 21:221-241

> Wootton J (1992) Indirect effects, prey susceptibility, and habitat selection: impacts of birds on limpets and algae. Ecology 73:981-991

> Worm B, Lotze H, Hillebrand H, Sommer U (2002) Consumer versus resource control of species diversity and ecosystem functioning. Nature 417:848-851

Yeates G (1969) Predation by Mononchoides potohikus (Nematoda: Diplogasteridae) in laboratory culture. Nematologica 15:3-9

> Yeates GW (1987) Nematode feeding and activity: the importance of development stages. Biol Fertil Soils 3:143-146

Yeates GW, Scott MB, Chown SL, Sinclair BJ (2009) Changes in soil nematode populations indicate an annual life cycle at Cape Hallett, Antarctica. Pedobiologia 52:375-386 